\title{
Application of Professional Sustainable Development to Improve Pedagogic Competence
}

\author{
Syahruddin $^{\text {a,1,*, }}$, Ahdan ${ }^{\text {a }}$, Ernawati ${ }^{\mathrm{a}}$ \\ ${ }^{a}$ Universitas Muslim Maros, Maros, Indonesia \\ ${ }^{1}$ syahruddinudin30@gmail.com
}

\begin{tabular}{|c|c|}
\hline Article Info & ABSTRACT \\
\hline $\begin{array}{l}\text { Article history: } \\
\text { Received: July 17, } 2019 \\
\text { Revised: August 19, } 2019 \\
\text { Accepted: August 30, } 2019\end{array}$ & $\begin{array}{l}\text { The purpose of this study is to explain the online mode of professional development } \\
\text { application in improving teacher competency of learners. The competencies intended } \\
\text { in this study are pedagogic competence and professional competence. The research } \\
\text { design was carried out in quantitative and qualitative forms. The number of research } \\
\text { samples is } 30 \text { people. Data collection method used is online media validation and } \\
\text { performance tests. Data analysis used descriptive statistics. The results showed } \\
\text { validation in the online mode of continuing professional development of the learning } \\
\text { teacher had an average value of total validity }=3.5 \text {. Thus, this value is included in the } \\
\text { category "Very Valid" (3.5 }<<4.0) \text {. Thus, online learning media teachers are } \\
\text { declared to meet the validity criteria. Then there are four online modal coaching } \\
\text { categories, namely (a) Knowing online features, (b) Writing down learning features, (c) } \\
\text { Writing out the names of activities, and (d) Describing the use of features in each } \\
\text { learning activity. }\end{array}$ \\
\hline
\end{tabular}

\section{INTRODUCTION}

Teachers as educators have a important role in determining the success of students [1], [2]. Therefore, it becomes a determinant factor in improving the quality of education [3], [4]. The importance of teachers's role is mandated in the Republic of Indonesia law Number 14 of 2005. It states that teachers and lecturers which mandates the development of the teaching profession as an actualization of the teaching profession.

To realize the mandate of the law as intended, the Ministry of Education and Culture implements a teacher competency improvement program for all teachers, both certified and uncertified. To implement the program, competency mapping has been carried out through teacher competency test. It aims to find out the teacher's current objective conditions and the need for increased competence.

This program is a process of organizing teaching and learning activities to improve the ability and competence of teachers. It is includes activities that aims to improve abilities, attitudes, and skills. It is expected to change a teacher behavior that significantly improve the performance of teaching and learning in the classroom.

Online mode in learning is a teacher program implemented by utilizing computer and internet network technology [5]-[7]. It can be implemented by preparing a learning system that independently provides instructions and learning services to participants without directly involving the users in the implementation process [8], [9]. The instructional system includes the registration process, learning implementation, final test, determination of graduation, and the issuance of certificates.

The online mode learning approach of continuous professional development program has a several characteristics, which are: (1) Demanding learners to build and create knowledge independently (constructivism). (2) Learners collaboration in building their knowledge and problem solving (social constructivism). (3) Establish an inclusive community of learners. (4) Utilizing a media page (website) that can be accessed via the internet, computer-based learning, and virtual classes. (5) Interactivity, independence, accessibility, and enrichment. 
Through this mode, participants have the flexibility of study time. They can learn anytime and anywhere, so there is no need to leave their obligations as teachers in educating. Participants can interact with mentors synchronously such as by using video conference, telephone or live chat. It also allows to interact asynchronous at different times through learning activities that have been provided electronically.

The online mode teacher learning system will export the participant's data to the Learning Management System (LMS) to be registered as an online mode teacher participant. The system uses a teacher module which is developed into learning activities formed as text, images, video and audio stored in the repository server. Data on all activities in the system will be evaluated using analytic tool/reporting software. A portfolio of learning outcomes for each participant will be recorded and stored in the database. The architecture of the online mode Teacher Learning system can be illustrated in online applications which can be accessed anytime and anywhere.

The application of online mode in improving teachers' pedagogical and professional competence is an innovation in developing human resources in the education world. The application of this system is not the only model for increasing teacher competency. However, an online mode can be used as a solution in developing learning models at schools. Thus, researchers try to find out how far it can improve the teachers' pedagogical and professional competence.

\section{METHOD}

This is a development research that will examine the content of online mode learning teachers according to the needs of a continuous professional development system for early grade elementary school teachers. Controlling system content is done with a centralized system in an online mode LMS. Furthermore, the data from the research instruments were analyzed to provide a quantitative and qualitative description of the pedagogical and professional competency improvement.

The variable in this study is the application of online mode continuous professional development in increasing the teachers' competency. The competencies intended in this study are pedagogical and professional. The data related to the variables are: (1) the application of online mode continuous professional development, (2) online mode guidance model, (3) the mechanism of implementing online mode activities, (4) the role of online mode in increasing the competence of teachers, (5) online mode learning activities, and (6) enhancing the teachers' pedagogical and professional competency.

The instruments that will be used in this study are observation notes regarding the symptoms investigated. It is related to the application of online mode continuous professional development programs. The observational notes are the results of the validation from three online mode validators. The second instrument is a performance tests to a sample of student teachers based on the pedagogical competency module and the teacher's professional competency sheet.
This research method is carried out through applied research that is based on research development methods. It aims to applying, testing, and evaluating the ability of a theory that is applied in solving practical problems. In addition, it is used to develop or validate a developed products in education and learning [10].

This research activity was carried out through six stages: (1) conducting a needs analysis, (2) examining online mode features, (3) developing an online mode application program, (4) conducting expert validation, (5) observing teacher activities online learners, and (6) analysis of primary and secondary data.

The data obtained in this study are primary and secondary data. Primary data formed as scores obtained through the results of media validation and performance tests through examinations of assignments in the teacher portfolio. Secondary is a teachers' perceptions of the system through a questionnaire.

All data collected is recorded and tabulated based on aspects that are used as variables. Then, the data are given their respective scores to facilitate interpretation. Data obtained through the application were analyzed using descriptive statistical techniques.

\section{RESULT AND DISCUSSION}

The online mode application is a website account of the learning process and increasing teacher competence online. The teacher as a participant conducts an online learning and can interact with other instructors, as well as fellow online mode learner participants. Teacher learning interaction online mode learners both online and face to face will form a learning community (community of learners). Following are the data analysis:

- The average value of validity for the preliminary session aspects in online mode learning is $V=3.4$. It can be concluded that this value is included in the category of "Valid" $(2.5<V<3.5)$.

- The average value of validity for learning session aspects presented through the learner's online teacher mode is $=3.5$. It can be concluded that this value is included in the category of "Very Valid" $(3.5<V<4.0)$.

- The average value of validity for the closing session aspects presented through the learner's online teacher mode is $=3.6$. It can be concluded that this value is included in the category of "Very Valid" $(3.5<V<4.0)$.

- The average total value of online mode validity and development of teacher professional learning is gained $=3.5$. It can be concluded that this value is included in the category of "Very Valid" $(3.5<V<4.0)$. It can be said that the media meet the validity criteria.

The model of online tutoring for teacher-learners is shown in their ability to understand the features in the online mode teacher learning system. Understanding these features is applied to practice using the features page, book, lesson, file, 
folder, message, forum, blog, e-portfolio, chat, and quiz on Moodle LMS.

Next, analyze the ability of participants to operate online mode features through the online mentoring. There are four activities in the application namely, (a) Get to know the features used in online mode learning, (b) Write the learning features used in each session appropriately, (c) Write the name of the activity on each session, and (d) Describe the use of features in each learning activity.

\section{A. Get to Know the Features used in Online Mode Learning}

The score of the participant's ability to understand in the form of recognizing the features of online mode learning of the teacher's continuing professional development can be seen in the Table 1.

TABLE I. ANALYSIS OF THE ABILITY TO UNDERSTAND ONLINE MODE LEARNING FEATURES

\begin{tabular}{clll}
\hline Interval Class & Frequency & Percentage $(\%)$ & Category \\
\hline $90-100$ & 14 & 46.7 & Excellent \\
$80-89$ & 10 & 33.3 & Good \\
$70-79$ & 5 & 16.7 & Moderate \\
$<70$ & 1 & 3.3 & Less \\
Total & 30 & 100 & \\
\hline
\end{tabular}

Table 1 shows that the 14 respondents (46.7\%) getting excellent category scores, 10 respondents (33.3\%) getting good grades, there are 5 respondents (16.7\%) received moderate category scores, and only 1 respondent $(3.3 \%)$ obtained less grades. The results of the descriptive statistical analysis showed that respondents' understanding of the features of the online mode is already good.

\section{B. Write Down the Learning Features used in Each Session Correctly}

TABLE II. ANALYSIS OF THE ABILITY TO WRITE LEARNING FEATURES

\begin{tabular}{llll}
\hline Interval Class & Frequency & Percentage $(\%)$ & Category \\
\hline $90-100$ & 12 & 40.0 & Excellent \\
$80-89$ & 15 & 50.0 & Good \\
$70-79$ & 3 & 10.0 & Moderate \\
$<70$ & 0 & 0 & Less \\
Total & 30 & 100 & \\
\hline
\end{tabular}

The score of the participant's ability to write the learning features used in each session can be correctly seen in the Table 2. It shows that the 12 respondents $(40 \%)$ get excellent category grades, 15 respondents $(50 \%)$ get good grades, there are 3 respondents (10\%) get moderate category scores, and no respondent $(0 \%)$ has less grades. The results of the descriptive statistical analysis show that the respondent's writing ability on the features of the PKB online mode for learner teachers is good.

\section{Write the Activity Name in Each Session}

The score of the participants' ability to write the name of the activity in each session correctly according to the learning features in the online mode can be seen in the Table 3 .
TABLE III. ANALYSIS OF ABILITY WRITING THE NAME OF THE ACTIVITY IN EACH LEARNING SESSION

\begin{tabular}{llll}
\hline Interval class & Frequency & Percentage $(\%)$ & Category \\
\hline $90-100$ & 9 & 30.0 & Excellent \\
$80-89$ & 12 & 40.0 & Good \\
$70-79$ & 6 & 20.0 & Moderate \\
$<70$ & 3 & 10.0 & Less \\
Total & 30 & 100 & \\
\hline
\end{tabular}

Table 3 shows that the 9 respondents (30\%) getting excellent category scores, 12 respondents $(40 \%)$ get good grades, there are 6 respondents $(20 \%)$ get moderate category scores, and there are only 3 respondents (10\%) who get less grades. Descriptive statistical analysis results show that the ability of respondents to write the name of the activity in each session correctly according to the learning features in the online mode is good.

\section{Describe the Use of Features in Each Learning Activity}

The value of the participant's ability to describe the use of features in each PKB online mode of learning activities of the teacher can be seen in the Table 4 .

TABLE IV. ANALYSIS RESULTS DESCRIPTION OF THE UTILIZATION OF FEATURES IN EACH LEARNING ACTIVITY

\begin{tabular}{llll}
\hline Interval class & Frequency & Percentage (\%) & Category \\
\hline $90-100$ & 7 & 23.3 & Excellent \\
$80-89$ & 14 & 46.7 & Good \\
$70-79$ & 5 & 16.7 & Moderate \\
$<70$ & 4 & 13.3 & Less \\
Total & 30 & 100 & \\
\hline
\end{tabular}

Based on Table 4, it shows that the 7 respondents $(23.3 \%)$ get excellent category, 14 respondents $(46.7 \%)$ get good grades, there are 5 respondents $(16.7 \%)$ get moderate category scores, and there are only 4 respondents $(13.3 \%)$ who get less grades. The results of the descriptive statistical analysis indicate that the ability of respondents to describe the benefits of the features in each of the online learning activities of the PKB online elementary school teacher learning model is good.

Thus, the application of the continuous professional development mode online early elementary school teacher learning application can be implemented through the mentoring method in four activities. The four activities are the application features of the learner's online mode, namely (a) Get to know the features used in online mode learning, (b) Write the learning features used in each session appropriately, (c) Write the name of the activity on each session correctly, and (d) Describe the use of features in each learning activity.

Based on the analysis, it can be illustrated the method of mentoring the online mode of the teacher learning four activities in the Figure 1. 


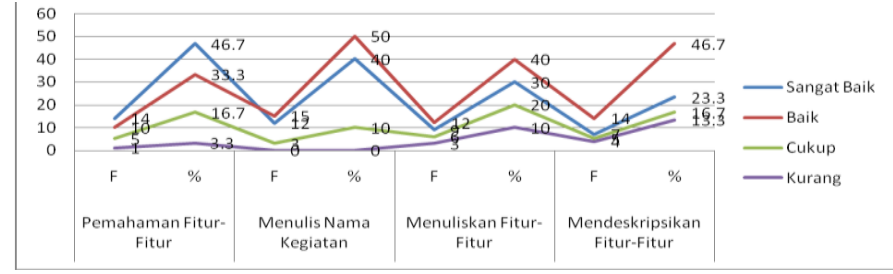

Fig. 1. Online mode mentoring method graph

Based on the Figure 1, the understanding of the features shows that 24 respondents $(80 \%)$ have received very good and good category scores, only 6 respondents (20\%) have received enough and less categories. The ability to write the name of the activity shows that 27 respondents $(90 \%)$ received very good and good category scores, only 3 respondents $(10 \%)$ received sufficient category scores, and none of the respondents received poor grades. The ability to write features shows 21 respondents $(70 \%)$ who received very good and good category scores, there were 9 respondents $(30 \%)$ who received sufficient and less category scores. The ability to describe the features shows 21 respondents $(70 \%)$ who received very good and good category scores, there were 9 respondents $(30 \%)$ who received sufficient and less category scores.

The learning approach of online mode learners teachers has the following characteristics: (1) Demanding learners to build and create knowledge independently (constructivism); (2) Learners will collaborate with other learners in building their knowledge and solving problems together (social constructivism); (3) Forming an inclusive community of learners; (4) Utilizing a media page (website) that can be accessed via the internet, computer-based learning, virtual classrooms, and / or digital classes; (5) Interactivity, independence, accessibility and enrichment;

General description of each learning model in online mode Learning Teachers, participants have the freedom of learning time. Participants can learn anytime and anywhere, so there is no need to leave their obligations as teachers in educating. Participants can interact with mentors/mentors synchronously - learning interactions at the same time such as by using video conference, telephone or live chat, or asynchronous - learning interactions at different times through learning activities that have been provided electronically.

Expert validation data obtained based on the assessment of material experts and media experts through the validation format of the online mode of learning design instrument in the professional development of the early elementary school teacher. Validated online learning design consists of a preliminary session, a learning session, and a closing session.

The preliminary session contained the introduction and demonstration of the system, the policy of developing and developing the teaching profession, a general explanation of the activities of online mode learning teachers, suggestions and how to use modules, and the learning flow.

Learning sessions contain material that must be mastered in accordance with the demands of learning outcomes. Learning activities carried out in learning sessions are introductions, learning activities, session forums, reflection, uploading assignments and comments, participant reactions, self-assessment, and session summative tests.

Furthermore, the closing session is the last session in the learning process of online mode learners where participants will carry out activities in it such as: conclusions and feedback, evaluations of the implementation of online mode learners, and the final test.

Based on the results of the validation in the online mode of the teacher's continuing professional development that the average value of total validity obtained is $=3.5$. Thus, this value is included in the category of "Very Valid" (3.5 $<V<4.0$ ). So, considering from all aspects of the online mode of continuing professional development of early grade elementary school teacher teachers, this media was declared to meet the validity criteria. Furthermore, the application of the continuous professional development mode online application for early grade elementary school teacher can be carried out through the mentoring method in four activities. The four activities are (a) Get to know the features used in online mode learning, (b) Write the learning features used in each session correctly, (c) Write the name of the activity in each session, and (d) Describe the use of features in each learning activity.

\section{CONCLUSION}

The application of online mode continuous professional development in improving pedagogical and professional competence of elementary school early grade teacher teachers in this study has been carried out through six stages, namely (1) conducting needs analysis, (2) developing online mode learning design, (3) developing web media-based learning, (4) validating experts, (5) testing instruments, and (6) reviewing / analyzing primary and secondary data. In addition, the focus of this research is the effectiveness of the use of online modes through web-based learning, the development of the continuous professionalism of learner teachers, and enhancing the pedagogical and professional competence of elementary school early grade teachers.

The average value of the total validity of online modes of learning professional development of learners obtained is = 3.5. Thus, it can be concluded that this value is included in the category of "Very Valid" $(3.5<V<4.0)$. So, considering from all aspects of the online mode of continuing professional development of early grade elementary school teacher teachers, this media was declared to meet the validity criteria.

The application of the ongoing professional development application for online modes of early grade elementary school teacher learning can be carried out through the mentoring method in four activities. The four activities are the application features of the learner's online mode, namely (a) Get to know the features used in online mode learning, (b) Write the learning features used in each session appropriately, (c) Write the name of the activity on each session, and (d) Describe the use of features in each learning activity.

Based on the results of this study, it is suggested to early grade elementary school learning teachers to utilize online mode learning media in improving pedagogical and 
professional competence. The online mode professional development application can improve pedagogical and professional competence of elementary school early grade teacher teachers. Furthermore, it is suggested to education managers to always encourage teachers to get used to using ICT media through online mode applications for sustainable professional development.

\section{References}

[1] D. Maor, "The Teacher's Role in Developing Interaction and Reflection in an Online Learning Community," EMI. Educ. Media Int., vol. 40, no. $1-2$, pp. 127-138, 2003.

[2] F. J. Tasiam, D. Kustono, P. Purnomo, and H. Elmunsyah, "Fostering pedagogic competence of electrical engineering vocational high school teacher in facing ASEAN economic community," Eur. J. Educ. Stud., vol. 3, no. 8, pp. 558-571, 2017

[3] J. Gore, A. Lloyd, M. Smith, J. Bowe, H. Ellis, and D. Lubans, "Effects of professional development on the quality of teaching: Results from a randomised controlled trial of Quality Teaching Rounds," Teach. Teach. Educ., vol. 68, pp. 99-113, 2017.

[4] A. Uka, "Student satisfaction as an indicator of quality in higher education," J. Educ. Instr. Stud. world, vol. 4, no. 3, pp. 6-10, 2014.

[5] M. Poe and M. Stassen, "Teaching and Learning Online: Communication, Community, and Assessment," A Handbook for UMass Faculty. Office of Academic Planning and Assessment, University of Massachusetts, Amherst, 2002.

[6] N. Bier, M. Lovett, and R. Seacord, "An Online Learning Approach to Information Systems Security Education," in Proceedings of the 15th Colloquium for Information Systems Security Education, 2011, pp. 5662.

[7] K. Shrain, "Moving towards e-learning paradigm: Readiness of higher education instructors in Palestine," Int. J. E-Learning, vol. 11, 2012.

[8] K. Thorne, Blended learning: how to integrate online \& traditional learning. London: Kogan Page Publishers, 2013.

[9] C. Limongelli, M. Lombardi, A. Marani, F. Sciarrone, and M. Temperini, "A recommendation module to help teachers build courses through the Moodle Learning Management System," New Rev. Hypermedia Multimed., vol. 22, no. 1-2, pp. 58-82, 2016.

[10] Sugiyono, Metode penelitian pendidikan, pendekatan kuantitatif, kualitatif, dan $R \& D$. Bandung: Alfabeta, 2010. 